\author{
EMILIA ŚMIECHOWSKA-PETROVSKIJ \\ Uniwersytet Kardynała Stefana Wyszyńskiego \\ $w$ Warszawie
}

\title{
WEZWANIE DO WLASNEJ AKTYWNOŚCI W KONTEKŚCIE DOBORU LITERATURY DLA DZIECI PRZEZ PEDAGOGÓW
}

Książka jest ważnym środkiem przekazu kulturowego, źródłem wiedzy, kształtowania postaw i sądów estetycznych. Kontakt dziecka z książką zakłada silny wpływ dorosłego pośrednika, bowiem pojawienie się potrzeb czytelniczych u dzieci nie jest zjawiskiem autonomicznym lecz efektem procesu inicjacji. W artykule omówiono zapośredniczenie kontaktu dziecka z książką jako efekt określonych wyborów i decyzji pedagoga w kontekście społecznych koncepcji uczenia się. Za kontynuację zagadnienia uznano uporządkowanie i zaprezentowanie obecnych w literaturze przedmiotu kryteriów doboru tekstów literackich dla dzieci w młodszym wieku szkolnym oraz wyników badań dotyczących preferencji profesjonalnych pośredników wobec własnej aktywności lekturowej i refleksyjności. Podjęte zagadnienia przedstawiono w optyce wezwania do samodzielnej aktywności, jako czynności oddziaływania pedagogicznego, sformułowanego przez Dietricha Bennera. W tym kontekście omówiono możliwości oddziaływania pedagogicznego poprzez odpowiedni dobór tekstów literackich, wskazując na nietożsamość funkcji pedagogicznej książki z funkcją wychowawczo-dydaktyczną i ukazując sferę kontaktu dziecka z książką jako obszar kształtowania świadomości istnienia różnych propozycji kulturowych i umiejętności samodzielnego wyboru z istniejących opcji. 


\section{Slowa kluczowe}

Literatura dla dzieci, pośrednik, wezwanie do własnej aktywności, kryteria doboru książek, preferencje lekturowe.

Znaczenie samodzielności w poznawaniu rzeczywistości przez jednostkę, kształtowanie czynnego stosunku do otaczających ją obiektów i zjawisk, refleksyjne podejście do własnego działania i sprawczości jest eksponowane we współczesnych rozważaniach pedagogicznych i teoriach uczenia się. W Pedagogice ogólnej Dietricha Bennera zagadnienia te znajdują wyraz w sformułowanych przez autora dwóch konstytutywnych zasadach myślenia i działania pedagogicznego. Należą do nich: podatność na kształtowanie (ukształcalność), rozumiana jako nieuwarunkowana żadnymi czynnikami zdolność do uczenia się, oraz wezwanie do samodzielnej aktywności, jako fundamentalna czynność oddziaływania pedagogicznego ${ }^{1}$. Zrozumienie ich może sprawić, że staną się one podstawą do wypracowywania takich form działania pedagogów, które będą wzmacniać aktywność i samosterowność danej osoby. Stwarzają również interesującą płaszczyznę dla rozważań dotyczących znaczenia dorosłego pośrednika w zdobywaniu wiedzy przez dzieci oraz w procesie kształtowania umiejętności samoodniesienia rozwijającej się jednostki.

Z perspektywy konstruktywizmu społecznego zmiana, która dokonuje się w rozwoju dziecka, wynika z jego interakcji z otaczającymi go obiektami i innymi ludźmi, inspirowanej zarówno przez dorosłych, jak i przez same dzieci, lecz musi być wzmacniana przez tych pierwszych - bardziej doświadczonych i kompetentnych ${ }^{2}$. „Dziecko nie odkrywa

${ }^{1}$ Por. D. Benner, Pedagogika ogólna, thum. z jęz. niem. M. Wojdak-Piątkowska, [w:] Pedagogika, red. B. Śliwerski, t. 1, Gdańskie Wydawnictwo Pedagogiczne, Gdańsk 2006, s. 156-172; tenże, Wprowadzenie Autora do wydania polskiego, [w:] tenże, Edukacja jako kształcenie i ksztattowanie. Moralność - kultura - demokracja - religia, thum. z jęz. niem. D. Stępkowski, Wydawnictwo Uniwersytetu Kardynała Stefana Wyszyńskiego, Warszawa 2008, s. 19.

2 Por. L. Wygotski, Narzędzie i znak w rozwoju dziecka, tłum. z jęz. ros. B. Grell, Państwowe Wydawnictwo Naukowe, Warszawa 1978, s. 45-47; M. Falkiewicz-Szult, Przemoc symboliczna w przedszkolu, Oficyna Wydawnicza „Impuls”, Kraków 2007. 
świata samo, ale przy wspierającej go obecności bardziej kompetentnego partnera [...] Uczenie się człowieka ma zawsze naturę społeczną, związaną z komunikacją i używaniem narzędzi kulturowych, jest rodzajem kulturowego oprzyrządowania umysłu"3. Komponent osobowy - obecność w procesie wychowywania oraz nauczania-uczenia się pedagoga (nauczyciela, wychowawcy, rodzica) może powodować, że oddziaływanie pedagogiczne będzie miało charakter opresyjny i narzucający.

Zgodnie z Bennerowskim ujęciem wezwanie do własnej aktywności, czyli pobudzenie do samodzielnego myślenia, działania i waloryzowania zarówno rzeczywistości, jak i swojej działalności, to wspieranie rozwoju rozumianego jako niezdefiniowane $\mathrm{z}$ góry przeznaczenie wychowanka i otwarta możliwość samostanowienia za pośrednictwem interakcji i dyskursu społecznego, nie zaś próba stworzenia dla tego rozwoju ram, ukonstytuowanych własną koncepcją wychowania pedagogów czy potrzebami społecznymi ${ }^{4}$. Wyłoniony tym samym paradoks działania pedagogicznego, w którym poprzez oddziaływanie zewnętrzne próbuje się wywołać autonomiczną decyzję o podjęciu czynności przez wychowanka oraz pobudzić go do refleksji, znajduje w myśli badacza następujące rozstrzygnięcie: „Praktyka pedagogiczna może, nawiązując do podatności na kształtowanie, wezwać wychowywanych do samodzielności tylko wtedy, gdy sprowokuje ich jednocześnie do współudziału we własnym procesie wychowania. Podstawowy paradoks myślenia i działania pedagogicznego ugruntowany na dialektyce obu pierwszych zasad, polegający na tym, że wzywa się wychowywanego do czegoś, czego ten jeszcze nie umie, i szanuje się go jako kogoś, kim jeszcze nie jest, lecz dopiero się stanie dzięki własnej samodzielności, podkreśla

${ }^{3}$ D. Klus-Stańska, J. Kruk, Tworzenie warunków dla rozwojowej zmiany poznawczej i konstruowania wiedzy przez dziecko, [w:] Pedagogika wczesnoszkolna-dyskursy, problemy, rozwiazania, red. D. Klus-Stańska, M. Szczepska-Pustkowska, Wydawnictwa Akademickie i Profesjonalne, Warszawa 2009, s. 468. Por. także: L. Wygotski, Myślenie i mowa, tłum. z jęz. ros. E. Flesznerowa, J. Fleszner, Państwowe Wydawnictwo Naukowe, Warszawa 1989; tenże, Narzędzie, dz. cyt., s. 45-47.

4 Por. D. Benner, Pedagogika ogólna, dz. cyt, s. 167; tenże, Wprowadzenie, dz. cyt., s. $20-21$. 
wyjątkowość praktyki pedagogicznej odróżniającej go od wszystkich innych praktyk"

\section{ZAPOŚREDNICZENIE KONTAKTU DZIECKA Z KSIĄŻKĄ}

Dziedziną wymagającą pośrednictwa bardziej niż inne obszary dziecięcego działania, a przy tym szczególnie narażoną na dyrektywne lub też zupełnie bezrefleksyjne traktowanie, jest kontakt dziecka z książką literacką. Książka jest ważnym środkiem przekazu kulturowego, źródłem wiedzy, kształtowania się potrzeb i sądów estetycznych. Komunikacja literacka małych dzieci wymaga silnego wpływu dorosłego pośrednika, bowiem pojawienie się potrzeb czytelniczych u nich nie jest zjawiskiem samorzutnym, lecz efektem procesu inicjacji, wprowadzenia książki w obręb doświadczeń osobistych dziecka oraz zapewnienia mu kontaktu literackiego poprzez głośne czytanie, recytację lub proponowanie lektury. Inicjacja literacka prowadzi do wykształcenia w dziecku autonomicznej potrzeby korzystania z dóbr kultury poprzez kształtowanie chęci i potrzeby czytania, wewnętrznej motywacji oraz wyposażenie dziecka w zasób umiejętności pozwalających te potrzeby zaspokajać6. „Inicjacja odbywa się przez gromadzenie doświadczeń, systematyzowanie ich $\mathrm{w}$ wiedzę ogólną, prowadzącą do wytworzenia pewnej aparatury poznawczej, to jest zespołu postaw odbiorczych wobec literatury"7. Wykształcenie potrzeb czytelniczych w toku pośredniczenia w przypadku małego dziecka, które nie opanowało jeszcze techniki samodzielnego czytania, a później proponowanie lektur, zanim jednostka będzie potrafiła sama tego dokonać, ma ogromne znaczenie, ponieważ czytanie jest rodzajem działalności kulturowej o wiele trudniejszej od innych ${ }^{8}$. Jest aktem ciągłej i intensywnej aktywności umysłowej, którą warunkują silne potrzeby indywidualne.

\footnotetext{
${ }^{5}$ D. Benner, Pedagogika ogólna, dz. cyt., s. 169.

${ }^{6}$ Por. J. Papuzińska, Inicjacje literackie, Wydawnictwa Szkolne i Pedagogiczne, Warszawa 1981, s. 203.

7 Tamże.

${ }^{8}$ Por. A. Wajda, Metodyka i organizacja czytelnictwa. Zarys ogólny, WSP w Bydgoszczy, Bydgoszcz 1979, s. 24.
} 
Zapośredniczenie kontaktu dziecka z książką jest wielopoziomowe: począwszy od kręgu rodzinnego, w którym kluczowe znaczenie ma decyzyjność rodziców, poprzez krąg instytucjonalny: wpływ nauczycieli, wychowawców, bibliotekarzy na wybór lektury dla dziecka, po krąg branżowy: krytyków literackich, instytucje zajmujące się propagowaniem czytelnictwa dziecięcego oraz wydawców i sieci dystrybucyjne. Pośrednik wybiera lekturę, opierając się na ocenie jej zawartości i swoim sądzie estetycznym (na podstawie własnej wiedzy i doświadczenia), a często również przekazuje swoją interpretację odbiorcy (poprzez sposób odczytywania, recytacji dzieła czy też swoistą cenzurę tekstu, opartą na przeświadczeniu o tym, co można dziecku zaprezentować, a czego nie). Jego obecność w kontakcie między dzieckiem a książką wpływa więc na jakość treści i formy tego medium.

W literaturze przedmiotu pojawiają się - w odniesieniu do niezbędnej obecności dorosłego w kontakcie dziecka z tekstem literackim - takie określenia jak: „podwójna konkretyzacja”9 literatury dla dzieci, prawo „prymarnego odbiorcy” (pierwszego interpretatora tekstu i obrazu) ${ }^{10}$, „oferta" doświadczeń społeczno-kulturowych przygotowana dla dzieci przez dorosłych ${ }^{11}$. Konstatują one rzeczywisty charakter komunikacji literackiej dzieci, w której pomiędzy małym odbiorcą a tekstem literackim znajduje się pośrednik, ale też kontestują tę swoistą relację nadawczo-odbiorczą jako wyraz przemocy symbolicznej, świadome lub nieświadome narzucanie znaczeń i wartości, których książka jest nośnikiem, wskazując na relację wiedzy/władzy, mającą wpływ na kształtowanie tożsamości dziecięcej w określonych (ograniczonych) „ramach kulturowych"12.

\footnotetext{
9 Por. J. Papuzińska, Inicjacje, dz. cyt., s. 180.

10 Por. M. Cackowska, Ksiązka obrazkowa dla dzieci, [w:] Pedagogika wczesnoszkolna, dz. cyt., s. 318 .

11 Por. D. Klus-Stańska, Światy dziecięcych znaczeń, Żak, Warszawa 2004, s. 8.

12 Por. M. Cackowska, dz. cyt., s. 312-320; P. Bourdieu, J. Passeron, Reprodukcja: elementy teorii systemu nauczania, thum. z jęz. ang. Neyman E., Państwowe Wydawnictwo Naukowe, Warszawa 2006; s. 71-150 ; M. Falkiewicz-Szult, dz. cyt.; Z. Melosik, T. Szkudlarek, Kultura, tożsamość i edukacja. Migotanie znaczeń, Oficyna Wydawnicza „Impuls”, Kraków 1998, s. 115-126.
} 
W edukacji wczesnoszkolnej decyzję o wyborze tekstu literackiego do przeczytania i omówienia podczas zajęć lekcyjnych scedowano na nauczyciela jako tego, który powinien wiedzieć, które utwory będą dla dzieci interesujące i staną się podstawą do ciekawych dyskusji i analiz. $\mathrm{Na}$ szczeblu ministerialnym podjęto więc decyzję o rezygnacji z listy lektur obowiązkowych (która dla klas I-III funkcjonowała przed reformą edukacji z 1999 roku). Umożliwienie nauczycielom wyboru utworów do omówienia spośród zarówno tekstów tradycyjnie należących do kanonu literatury dziecięcej, jak i nowości wydawniczych (właśnie poprzez zniesienie listy lektur) tym mocniej kieruje uwagę na motywy wyborów nauczycieli, określenie, czy są one świadome, czy wynikają z obranych założeń, co do edukacji i wychowania dziecka, czy też są bezrefleksyjne, a także w jakim stopniu są konsekwencją ograniczonej lub pełnej wiedzy pośredników na temat literatury dziecięcej.

\section{KRYTERIA DOBORU TEKSTÓW LITERACKICH DLA DZIECI}

Współcześnie w literaturze przedmiotu można znaleźć następujące kryteria doboru tekstów literackich dla dzieci w młodszym wieku szkolnym: 1. Kryteria ramowo określone w podstawie programowej kształcenia ogólnego:

A. Uwzględniające właściwości wewnątrztekstowe:

a) kryterium pragmatyczne (taki dobór tekstów, by możliwe było rzetelne ich omówienie, stąd wymóg, by w szkole podstawowej omówić przynajmniej cztery pozycje książkowe w ciągu roku);

b) kryterium estetyczne (rozumiane, jako kryterium atrakcyjności tekstu dla ucznia i będące sposobem wykształcenia w uczniach nawyku czytania);

c) kryterium poznawcze (proponowane teksty mają służyć przekazaniu wiedzy zarówno o rzeczywistości, jak i o kulturze - konwencjach literackich oraz dziejach literatury i kultury).

B. Uwzględniające możliwości odbiorcze dziecka oraz dydaktyczno-wychowawczą funkcję szkoły: 
a) kryterium gatunkowe: dobór utworów, uwzględniający takie gatunki literatury dziecięcej, jak: baśnie, bajki, legendy, opowiadania, wiersze, komiksy;

b) kryterium potrzeb wychowawczych i edukacyjnych ${ }^{13}$.

2. Psycho-dydaktyczne kryteria doboru książek dla dzieci ${ }^{14}$ :

- uwzględnianie i zaspokajanie potrzeb czytelniczych dzieci (przyjemności czytania, emocji, wiedzy, marzenia, kombinowania - myślenia dedukcyjnego ${ }^{15}$ );

- uwzględnienie stadialności rozwoju czytania pociągającej za sobą konieczność dostosowania lektury do możliwości czytelniczych dziecka i stymulowania rozwoju czytania;

- uwzględnienie kategorii czytania osiąganych przez dzieci: czytania receptywnego, czytania krytycznego oraz czytania twórczego;

- uwzględnienie konieczności organizowania procesu kształtowania umiejętności rozumienia tekstu.

3. Cechy utworów literackich przydatne przy ocenie pozycji czytelniczej:

- tematyka utworu literackiego,

- gatunek literacki,

- autor,

- wartości artystyczne lektur,

- cechy struktury (objętość, książka - utwór, książka - zbiór utworów),

- specyfika spisu treści,

- liczba i układ rozdziałów,

- sposób ilustrowania,

- typ ilustracji,

- aspekty edytorskie ${ }^{16}$

13 Por. Podstawa programowa z komentarzami. Tom 2. Język polski w szkole podstawowej, gimnazjum i liceum, MEN, Warszawa 2009. s. 15-18, 25-28, 55-59.

14 Por. M. Głoskowska-Sołdatow, Psycho-dydaktyczne uwarunkowania doboru lektury dla dzieci 7-10 letnich, [w:] Walory edukacyjne literatury dziecięcej, red. J. Chruścińska, E. Kubisz, Centrum Ustawicznego Kształcenia Bibliotekarzy, Warszawa 2000, s. 23-29.

15 Por. A. Baluch, Proces czytania, [w:] Wczesnoszkolna edukacja literacka, red. B. Dymara, Oficyna Wydawnicza „Impuls”, Kraków 1996, s. 37-41.

16 Por. E. Szefler, Ksiązka literacka dla dziecka w edukacji wczesnoszkolnej, WSP w Bydgoszczy, Bydgoszcz 1998, s. 12. 
4. Publikacje autorstwa literaturoznawców, krytyków literackich lub pisarzy prezentujące tytuły ich zdaniem wartościowe i godne polecenia ${ }^{17}$. Charakterystyka tych opracowań i wskazywane motywy wydania są podobne. Autorzy powołują się na własne, subiektywne odczucie ważności lub wartości danych utworów, wskazując na potrzebę ich popularyzacji, określenia ważnych obszarów interpretacyjnych, a przez to pomocy dorosłym w wyborze lektur dla dzieci oraz ich omówieniu. We wstępach lub posłowiach do tych publikacji pojawiają się wypowiedzi o podobnym wydźwięku. „Książka ta pełni rolę przewodnika - najpierw dla pośrednika lektury dla dzieci małych, potem dla doradcy lektury dzieci starszych i nastolatków. [...] W każdym małym rozdzialiku prezentowane są tytuły dobrych wartościowych książek, które stanowią «kanon» dla zainteresowanego czytelnika"18. „Książeczka ta powstała z myślą o nauczycielach, tych zwłaszcza, którzy zamierzają urozmaicić stosowane programy nauczania, albo też sami je tworzą. [...] Nie proponuję żadnych konkretnych rozwiązań z zakresu metodyki nauczania, zakładam, że nauczyciele poradzą sobie z tym o wiele lepiej ode mnie, chodziło mi raczej o rekomendację samych tekstów. Zakładam po cichu, że jeśli nawet nie wszystkie moje podpowiedzi repertuarowe trafią bezpośrednio do młodzieży, czy dzieci, mogą one przydać się samym nauczycielom, dopomóc im w jakichś własnych przemyśleniach czy rozwiązywanych problemach"19.

5. Listy lektur rekomendowanych przez różne gremia. W tym obszarze można wymienić książki wyróżnione i nagrodzone w konkursach, na przykład Polskiej Sekcji IBBY „Książka Roku” czy „Nagroda Donga” (dawniej „Dziecięcy Bestseller Roku”), w Konkursie Literatury

17 Przykładową reprezentacją takich publikacji są: J. Hartwig-Sosnowska, Wyobraźnia bez granic, Młodzieżowa Agencja Wydawnicza, Warszawa 1987; J. Papuzińska, Drukowana ścieżka, Wydawnictwo Literatura, Łódź 2000; A. Baluch, Książa jest światem, Universitas, Kraków 2005; E. Szefler, Książka literacka, dz. cyt.; W. Kostecka, Tajemnica księgi. Tropami wspótczesnej fantastyki dla dzieci i młodzieży, Wydawnictwo Naukowe Scholar, Warszawa 2010.

18 A. Baluch, Książka, dz. cyt., s. 7.

19 J. Papuzińska, Drukowana, dz. cyt., s.108. 
Dziecięcej organizowanym przez Muzeum Książki Dziecięcej oraz umieszczane na Złotej Liście Książek do czytania dzieciom opracowanej przez Fundację ABCXXI - Cała Polska Czyta Dzieciom. Celem wymienionych nagród jest promocja książek dla dzieci wartościowych literacko i artystycznie, a oceniane są walory literackie, plastyczne, merytoryczne oraz staranność wydania ${ }^{20}$. Kryteria doboru lektur i wpisania ich na listę, które stosuje Fundacja ABCXXI są nieco inne: przede wszystkim wybierane są pozycje oceniane jako najlepsze do głośnego odczytywania dzieciom. Utwory mają służyć zarówno podnoszeniu ogólnego poziomu kultury i wiedzy, jak i wspierać i ochraniać zdrowie emocjonalne dziecka, rozumiane jako dobre samopoczucie psychiczne oraz moralne, a także umiejętność racjonalnego myślenia oraz zdolność nawiązywania dobrych i trwałych związków z ludźmi ${ }^{21}$.

6. Prezentacje, recenzje, rekomendacje ukazujące się w czasopiśmiennictwie dotyczącym książek dla dzieci i młodzieży.

Zaproponowany „wykaz” ujmuje funkcjonujące w literaturze podejścia do tekstu literackiego dla dzieci w młodszym wieku szkolnym, z którego mogą skorzystać nauczyciele. Współcześnie niewiele jest jednak wyników badań empirycznych określających, czy i w jakim stopniu dorośli pośrednicy korzystają z tych konkretnych propozycji oceny formy i zawartości treściowej tekstów w procesie dokonywania wyboru lektury.

W dostępnych badaniach analizowane są preferencje lekturowe nauczycieli, studentów, rodziców i ich kryteria doboru książek dla dzieci. Namysł nad wyborami dokonywanymi spośród publikacji dostępnych w ofercie wydawniczej pośrednio pozwala wysunąć wniosek dotyczący stosunku ich odbiorców do przekazywanych treści oraz określić, czy selekcja książek dokonywana jest według określonych myśli przewod-

${ }^{20}$ Por. hasło: IBBY, [w:] Stownik literatury dziecięcej i młodzieżowej, red. B. Tylicka, G. Leszczyński, Zakład Narodowy im. Ossolińskich, Wrocław 2002, s. 155-156.

${ }^{21}$ Por. Ztota Lista Ksiażek do czytania dzieciom opracowana przez Fundację ABCXXI - Cała Polska czyta dzieciom, dostępna na: http://www.calapolskaczytadzieciom.pl/zlota-lista, (dostęp: 11.05.2011). 
nich $^{22}$. W kolejnej części artykułu dokonano przeglądu rezultatów badawczych dotyczących tej problematyki.

\section{PRZEGLĄD BADAŃ DOTYCZĄCYCH KRYTERIÓW DOBORU UTWORÓW LITERACKICH DLA DZIECI PRZEZ DOROSŁYCH POŚREDNIKÓW}

W latach 80., podsumowując wyniki badań ustalających perspektywy, z jakich dorośli pośrednicy oceniają tekst literacki dla dzieci, Joanna Papuzińska konstatowała, że pedagodzy i nauczyciele często nie rozumieją i nie znają nowych prądów literackich. Badaczka wskazywała, że preferują oni teksty tradycyjne, bagatelizując w swoich wyborach autorów współczesnych. Podkreślała również problem jednostronnej interpretacji tekstów literackich, sprowadzanej do wskazywania wzorców zachowań i postaw oraz referowania rzeczywistości. Ocena tekstów literackich dla dzieci przez respondentów uwzględniała komponent jakościowy $-28 \%$ badanych uznawało funkcje estetyczne książek za ważne, ale wyrażano je konwencjonalnie, poprzez określenia typu ładne-brzydkie, odnoszono się głównie do szaty graficznej i języka - szkolnych wzorców poprawności. Włączano też do obszaru estetyki utworów dziecięcych inne elementy, np. prezentowanie wzorów pozytywnych jako kryterium przyznania wartości estetycznej książce. Prezentowanie pozytywnych wzorców zachowań jako odrębne kryterium pozytywnej oceny książki dla dzieci wskazało $24 \%$ respondentów. Inne kryteria wskazywano następująco: realizacja potrzeb poznawczych (dostarczenia wiedzy o świecie zewnętrznym) $-17 \%$ badanych, potrzeba rozrywki $-8,6 \%$, potrzeba kompensacji $-5 \%$ respondentów. W przeprowadzonym badaniu przychylnie oceniane były takie gatunki jak: bajeczka dziecięca (oparta na schematach ezopowych), opowiadania realistyczne z życia dzieci (prezentujące przewinienie oraz poprawę), baśnie literackie. Wyżej oceniano utwory starszego pokolenia o znanych nazwi-

\footnotetext{
22 Por. M. Krasuska-Betiuk, Badania kultury literackiej młodzieży studiującej. Propozycja teoretyczno- metodologiczna, „Kultura i Edukacja” 3(2004), s. 82.
} 
skach niż młodszego pokolenia (mimo zdobytego uznania), pedagodzy wykazywali więc zaufanie autorytetom. Nauczyciele wybierali utwory znane, tradycyjnie uznawane za wartościowe dla dzieci, ze szczególnym uwzględnieniem tych, które mogły pełnić funkcję dydaktyczną, informatorską i społeczną. Prezentowany przez badanych poziom kultury literackiej nie był wysoki, z czego zdaniem Joanny Papuzińskiej wynikała niemożność ustosunkowania się do tekstów czerpiących ze współczesnych prądów literackich. Rzadko odwoływali się do kryterium oryginalności i niepowtarzalności tekstu, a także do autonomicznych funkcji tekstu literackiego.

Inny kierunek namysłu nad wyborami utworów dla dzieci przez nauczycieli dotyczy lektur przemilczanych, nieomawianych, określonych przez Małgorzatę Dagiel i Dorotę Klus-Stańską jako lektury „skreślone zaocznie"23. Wyniki przeprowadzonego przez Małgorzatę Dagiel sondażu diagnostycznego na grupie czynnych zawodowo nauczycieli nauczania początkowego pokazały, że:

- nie wszyscy nauczyciele znali lektury z kanonu klas I-III (badania przeprowadzono przed reformą edukacji, kiedy funkcjonowała lista lektur obowiązkowych),

- byli nauczyciele, którzy nie akceptowali wielu utworów fantastycznych (niektórych baśni literackich z wyłączeniem utworów Andersena, legend i baśni ludowych) jako odpowiednich do pracy szkolnej,

- poezja bywała odrzucana częściej niż utwory prozatorskie,

- wśród motywów dokonywanych wyborów pojawiały się takie, jak: znajomość danej lektury, własne upodobania, eksponowana w lekturze funkcja poznawcza i wychowawcza, przeświadczenie o przystępności tekstu tak dla nauczycieli, jak i dla uczniów; stawały się one kryteriami odrzucania niektórych tekstów, skreślania ich z listy utworów do omówienia.

${ }^{23}$ Por. M. Dagiel, D. Klus-Stańska, Powierzchniowa idealizacja świata w interpretacjach literatury dziecięcej i lektury ,,skreślone zaocznie”, [w:] Edukacja polonistyczna na rozdrożach, red. D. Klus-Stańska, M. Dagiel, Wydawnictwo Uniwersytetu Warmińsko-Mazurskiego, Olsztyn 1999, s. 64-72. 
Ciekawych wyników dostarczyły także, przeprowadzone w latach 2006-2007 w Wielkiej Brytanii na próbie 1200 nauczycieli wczesnej edukacji, badania zależności pomiędzy wyborami i preferencjami lekturowymi nauczycieli jako czytelników a wyborami lektur do pracy z uczniami w warunkach szkolnych. Pokazały one, że nauczyciele mają wąski repertuar poetów, pisarzy i ilustratorów zajmujących się literaturą dla dzieci. Podczas gdy w prywatnej praktyce czytelniczej (czytanie dla przyjemności) wybierali różnych autorów i tytuły, zarówno rodzimą literaturę, jak i światową, podobna tendencja nie była odzwierciedlona w ich wyborach literatury dla dzieci ${ }^{24}$. Ulubione utwory literatury dziecięcej $\mathrm{w}$ opinii nauczycieli to $\mathrm{w}$ zdecydowanej większości proza popularna (60\% wypowiedzi), wiele wskazań dotyczyło również XX-wiecznych klasycznych tekstów. $10 \%$ nauczycieli wybrało dziewiętnastowieczne klasyczne utwory, bardzo niewielu respondentów $(1,5 \%)$ wskazało na poezję jako ulubioną lekturę dzieciństwa. Proszeni o wskazanie 6 pisarzy, 6 poetów i 6 ilustratorów w dziedzinie twórczości literackiej dla dzieci nauczyciele najlepiej radzili sobie z podaniem prozatorów $-64 \%$ respondentów wskazało na 5 lub 6 pisarzy (powracało jednak we wskazaniach tylko kilka nazwisk pisarzy), podczas gdy w odniesieniu do poetów ich wiedza była znacznie mniejsza: $58 \%$ to wskazania jednego, dwóch poetów lub żadnego, tylko 10\% wypowiedzi wskazało na sześciu poetów; podobnie w przypadku ilustratorów: $62 \%$ podawało nazwisko jednego, dwóch lub żadnego, tylko $10 \%$ podało 6 nazwisk.

Niski poziom wiedzy o literaturze dla dzieci może być niepokojący, zwłaszcza gdy zestawi się go z kryteriami, jakie stosowali respondenci przy wyborze literatury dla dzieci. Kierowali się:

- wiedzą i zainteresowaniami czytelniczymi (85\%),

- dziecięcą rekomendacją i potrzebą czytelniczą (64\%),

${ }^{24}$ Por. T. Cremin, E. Bearne, M. Mottram, P. Goodwin, Primary teachers as readers, „English in Education” 42(2008)1, s. 8-23; T. Cremin, M. Mottram, E. Bearne, P. Goodwin, Exploring teachers 'knowledge of children's literature, „Cambridge Journal of Education" 38(2008)4, s. 449-464; T. Cremin, M. Mottram, F. Collins, S. Powell, K. Safford, Teachers as readers: building communities of readers, „Literacy” 43(2009)1, s. 11-19. 
- wytycznymi szkolnego koordynatora edukacyjnego (31\%),

- rekomendacją bibliotekarzy (21\%).

Nieco inny kierunek badań prezentuje Małgorzata Cackowska, która analizowała sądy nauczycieli i rodziców edukacji wczesnoszkolnej ${ }^{25}$ i na ich podstawie wnioskowała o standardach oczekiwań dotyczących książki dla dzieci. Badaczka wyłoniła potoczne koncepcje książki obrazkowej dla dzieci. W propozycjach zawartych w narracji osób badanych znalazły się koncepcje „książki kolorowej”, „książki realistycznej”, „książki szablonowej”, „książki idyllicznej”, które odzwierciedlają schematyzm dominujących na polskim rynku wydawniczym książek dla dzieci, o nikłych walorach treściowych, literackich i plastycznych. Badaczka konstatuje: „Gust znaczących «pośredników», którym podobają się śliczne, kolorowe, jaskrawe, wesołe, sielskie i szablonowe obrazki ilustrujące [...] historyjki oparte na stereotypach, zdaje się być poważną zaporą przed współobecnością w ilustracji dla dzieci najnowszej estetyki artystycznej: wymagającej, aluzyjnej, refleksyjnej, nieoczywistej, przed otwarciem się na tzw. tematy trudne (jak wojna, śmierć, choroba), przed demokratyzacją społeczeństwa niesioną przez np. przełamywanie stereotypów płci, czy też odbrązawianie wizerunku dorosłego w książkach dla dzieci"26.

Wybrane spośród nielicznej reprezentacji badania, choć przeprowadzone w różnym czasie (niekiedy w odstępie ponad 20 lat), na różniącej się populacji (nauczyciele polscy, nauczyciele brytyjscy), prezentują niepokojący obraz pośredników w procesie doboru utworów dla dzieci w młodszym wieku szkolnym. Niedostatek wiedzy w zakresie literatury dziecięcej i młodzieżowej pedagogów, skłanianie się ku utworom tradycyjnym, mimo możliwości wyboru książek współczesnych, akcentowanie funkcji pozaestetycznych literatury - poznawczych i instrumentalno-wychowawczych, nastawionych na prezentowanie

25 Por. M. Cackowska, Pozycja dorostych „pośredników” w konstruowaniu estetyki treści i formy ilustrowanej ksiązki dla dzieci, [w:] Dziecko - teksty - znaczenia. Konteksty edukacyjne i rozwojowe, red. A. Wasilewska, Wydawnictwo Uniwersytetu Gdańskiego 2007, s. 135-151.

${ }^{26}$ M. Cackowska, Książka obrazkowa, dz. cyt., s. 327. 
pozytywnych wzorców zachowań i postaw, unikanie tematów trudnych, prezentowanie często spłaszczonego obrazu świata, może negatywnie oddziaływać na inkulturację dzieci, konstruowanie wiedzy w ich umysłach oraz kształtowanie kultury czytelniczej. Może prowadzić do wychowywania do schematycznego myślenia i bezrefleksyjnych wyborów (poprzez selekcję książek tożsamą z selekcją znaczeń, jakie one niosą, dokonywaną przez pośredników), bowiem wiedza uczniów powstaje na styku dwóch obszarów: przestrzeni samodzielnego myślenia oraz przestrzeni przekazu dorosłych ${ }^{27}$, „to czego dziecko doświadcza, co wybiera dla własnego rozwoju, zależy w równym stopniu od tego, co i jak mu się oferuje" 28 .

\section{DOBÓR LITERATURY JAKO WEZWANIE DO WLASNEJ AKTYWNOŚCI}

Zygmunt Bauman w książce Kultura w płynnej nowoczesności stwierdza, że: „Kultura składa się dziś z ofert, nie nakazów; z propozycji, a nie norm" 29 . Jednak zapośredniczenie jakiegoś jej elementu, np. sfery kontaktu dziecka z książką, sprawia, że w tym wyodrębnionym obszarze przestaje być pełną ofertą, staje się limitowanym wyborem opartym na cudzej optyce oraz waloryzacji znaczeń i wartości sprzężonych z formą i treścią tekstu literackiego. W tym kontekście można stwierdzić, że sposób dobierania książek dla dzieci przez dorosłych pośredników warunkuje wykształcenie się autonomicznej potrzeby korzystania z dóbr kultury oraz kształtuje autonomię wyborów dziecka w ogóle - o ile proponowane lektury pod względem treściowym i formalnym będą niejednorodne, w swojej wymowie niedogmatyczne, nielimitowa-

27 Por. D. Klus-Stańska, Od niechęci wobec dziecięcej samodzielności myślenia do przekazu fikcji społecznej, „Studia Pedagogiczne Uniwersytetu Humanistyczno-Przyrodniczego Jana Kochanowskiego" 18(2009), s. 20.

28 D. Karwowska-Struczyk, Rozwój dzieci a ich aktywność, „Wychowanie w Przedszkolu", 4(2000), s. 206.

29 Z. Bauman, Kultura w plynnej nowoczesności, Agora, Warszawa 2011, s. 27. 
ne określonymi założeniami, co do wychowania dziecka, prezentujące różnorodność świata.

Zrozumienie znaczenia kontaktu dziecka z książką jako jednej z praktyk pedagogicznych mogących do samodzielności wzywać wymaga przeprowadzenia rozgraniczenia pomiędzy tradycyjnie rozumiana pedagogiczną funkcją książki (dydaktyczno-wychowawczą, instrumentalną, a zatem uznającą młodego czytelnika jedynie jako przedmiot zamierzonego przez dorosłych oddziaływania za pośrednictwem książki) a uznaniem komunikacji literackiej dziecka jako obszaru doświadczania wielowymiarowego świata i otwartych, a nie z góry określonych sensów prezentowanej rzeczywistości.

Inaczej ujmując to zagadnienie, warto odwołać się do dwóch typów krytyki książki dziecięcej omówionych przez Grzegorza Leszczyńskiego w tekście $O$ krytyce ksiązki dziecięcej ${ }^{30}$. Autor prezentuje w ogóle cztery krytyczne podejścia do literatury dla dzieci: pedagogiczne, socjologiczne, estetyczne i paistyczne. Omawiając krytykę pedagogiczną, badacz podkreśla, iż ta praktyka analizowania, a następnie wartościowania dzieła, opiera się na stawianych mu wymaganiach formowania postaw, poglądów czytelnika oraz kształtowania jego wiedzy o świecie empirycznym ${ }^{31}$ i nie uwzględnia koncepcji estetycznych, które utwór realizuje, lub je marginalizuje. Natomiast, prezentując krytykę estetyczną, podkreśla jej nastawienie na poszukiwanie w niej ważnych treści humanistycznych, finezji artystycznej, formalnej lub treściowej innowacyjności. „Podstawowym zadaniem krytyka [w nurcie estetycznym] jest udzielenie odpowiedzi na pytanie o takie wartości estetyczne książki, które są możliwe do percepcji przez hipotetycznego odbiorcę [...] Innymi słowy: krytyk ocenia i analizuje wartości artystyczne, ich sposoby aktualizacji w dziele, konwencji, tradycji”32.

To, co w powyższym przytoczeniu określone jest mianem ,pedagogicznego", a wcześniej zostało omówione jako tradycyjnie rozumiana

${ }^{30}$ Por. G. Leszczyński, O krytyce ksiażki dziecięcej, [w:] tenże, Literatura i ksiażka dziecięca, Centrum Edukacji Bibliotekarskiej, Informacyjnej i Dokumentacyjnej, Warszawa 2003, s. 19-42.

31 Por. tamże, s. 21.

32 Tamże, s. 24. 
funkcja pedagogiczna książki, nie jest - jak łatwo to uchwycić - tożsame z postulowanym i opartym na koncepcji Dietricha Bennera wykorzystaniem książki w oddziaływaniu pedagogicznym jako wezwaniem do własnej aktywności.

Niezgoda na potraktowanie tekstów literackich wyłącznie jako instrumentarium dydaktyczno-wychowawczego nie powoduje jednak wyboru perspektywy estetycznej jako nadrzędnej. Chodzi raczej o wrażliwość pośredników zarówno na walory wychowawcze i poznawcze danego utworu, jak też estetyczne, ale również uwzględnienie perspektywy paistycznej ${ }^{33}$ - dziecięcego odczytywania utworu, dziecięcego stylu lektury. Mając na uwadze te perspektywy oceny tekstów literackich dla dzieci z jednej strony oraz świadomość, iż tylko prezentując wielowymiarową rzeczywistość stwarzamy warunki dla doświadczania przez dziecko własnej niezależności i samodzielnych wyborów, możemy poprzez proponowaną lekturę wzywać do własnej aktywności jednostkę i angażować ją w proces wychowania. Dzieje się to nie poprzez aplikowanie wyselekcjonowanych znaczeń, sprzężonych z treścią celowo wybranej (lub bezrefleksyjnie - co zdaje się równie niebezpieczne jak dyrektywne wybory) lektury, lecz poprzez rzeczywiste proponowanie różnorodnych tekstów, czyli kształtowanie świadomości istnienia różnych propozycji kulturowych i umiejętności wyboru z alterujących opcji (oczywiście, dzięki zapewnieniu wcześniej możliwości refleksji nad nimi).

Na tym polega wsparcie pedagogiczne dziecka w procesie pośredniczenia na jego rzecz w doborze tekstów literackich. Jest ono możliwe tylko dzięki szacunkowi dla wychowanka jako kogoś, kim jeszcze nie jest, ale kim się stanie. Dzięki temu, w myśl konstatacji Dariusza Stępkowskiego, wychowanek,,stopniowo kształtuje w sobie relacje samoodniesienia (Selbstverhältnis) do treści nauczania-uczenia się [w omawianym przypadku - do propozycji lekturowych i wizji świata oraz wartości estetycznych sprzężonych z nimi]. Dzięki tej relacji zostaje on uzdolniony do odpowiedzialnego myślenia i działania" ${ }^{34}$.

\footnotetext{
33 Por. tamże, s. 26.

34 D. Stępkowski, (R)ewolucja prakseologiczna w myśleniu i działaniu pedagogicznym wedlug Dietricha Bennera, „Seminare” 24(2007), s. 435.
} 


\section{PODSUMOWANIE}

Wezwanie do własnej aktywności w kontekście doboru literatury dla dzieci przez pedagogów - dorosłych pośredników w komunikacji literackiej dzieci może być rozważane na dwóch poziomach uszczegółowienia:

- na poziomie konkretnych propozycji treściowych i formalnych (czego reprezentacją są przytoczone wcześniej wyniki badań, jako negatywne praktyki doboru tekstów literackich przez dorosłych na rzecz dzieci, szczególnie konstatacje D. Klus-Stańskiej i M. Cackowskiej);

- na poziomie wyższym i ogólniejszym, dotyczącym samego podejścia do literackiej książki dla dzieci (wobec przekonania o wciąż zmieniającej się rzeczywistości kulturowo-społecznej) jako przestrzeni, w której może dokonywać się transgresja autorytetu pedagogicznego (pośrednika z szacunkiem podchodzącego do dziecka poprzez oferowane mu książki) w wewnętrzny autorytet dorastającej jednostki (zdolnej dokonywać samodzielnych wyborów i świadomej możliwych opcji).

Odnosi się również do dwóch podmiotów interakcji pedagogicznej: pedagogów i dzieci. Bowiem i ci pierwsi muszą się ,samowezwać” do aktywności, by dokonywane przez nich wybory i praktyka lekturowa zmieniły utrzymującą się od wielu lat złą jakość pośredniczenia pomiędzy książką literacką a dzieckiem w młodszym wieku szkolnym. Stąd konieczność pedagogizacji pośredników różnymi sposobami, również poprzez systematyzowanie istniejących w literaturze przedmiotu propozycji kryteriów doboru książek literackich dla dzieci oraz prezentowanie negatywnych wyników badań, by prowokować działania ewaluacyjne i ukierunkować na pozytywną zmianę.

\section{BIBLIOGRAFIA}

Baluch A., Książka jest światem, Universitas, Kraków 2005.

Baluch A., Proces czytania, [w:] Wczesnoszkolna edukacja literacka, red. B. Dymara, Oficyna Wydawnicza „Impuls”, Kraków 1996. 
Bauman Z. Kultura w plynnej nowoczesności, Agora, Warszawa 2011.

Benner D., Edukacjajako ksztatcenie i kształtowanie. Moralność-kultura-demokracja-religia, wyb. i thum. D. Stępkowski, Wydawnictwo Uniwersytetu Kardynała Stefana Wyszyńskiego, Warszawa 2008.

Benner D., Pedagogika ogólna, thum. jęz. niem. M. Wojdak-Piątkowska, [w:] Pedagogika, red. B. Śliwerski, t. 1, Gdańskie Wydawnictwo Pedagogiczne, Gdańsk 2006.

Bourdieu P., Passeron J., Reprodukcja: elementy teorii systemu nauczania, tłum. z jęz. ang. E. Neyman, Państwowe Wydawnictwo Naukowe, Warszawa 2006.

Cackowska M., Ksiązka obrazkowa dla dzieci, [w:] Pedagogika wczesnoszkolna - dyskursy, problemy, rozwiazania, red. D. Klus-Stańska, M. Szczepska-Pustkowska, Wydawnictwa Akademickie i Profesjonalne, Warszawa 2009.

Cackowska M., Pozycja dorostych „pośredników” w konstruowaniu estetyki treści i formy ilustrowanej książki dla dzieci, [w:] Dziecko - teksty - znaczenia. Konteksty edukacyjne i rozwojowe, red. A. Wasilewska, Wydawnictwo Uniwersytetu Gdańskiego, Gdańsk 2007.

Cremin T., Bearne E., Mottram M., Goodwin P., Primary teachers as readers, „English in Education” 42(2008)1.

Cremin T., Mottram M, Bearne E., Goodwin P., Exploring teachers' knowledge of children's literature, „Cambridge Journal of Education” 38(2008)4.

Cremin T., Mottram, M., Collins F., Powell S., Safford K., Teachers as readers: building communities of readers, „Literacy” 43(2009)1.

Dagiel M., Klus-Stańska D., Powierzchniowa idealizacja świata w interpretacjach literatury dziecięcej i lektury ,, skreślone zaocznie”, w: Edukacja polonistyczna na rozdrożach, red. D. Klus-Stańska, M. Dagiel, Wydawnictwo Uniwersytetu Warmińsko-Mazurskiego, Olsztyn 1999.

Falkiewicz-Szult M., Przemoc symboliczna w przedszkolu, Oficyna Wydawnicza „Impuls”, Kraków 2007.

Głoskowska-Sołdatow M., Psycho-dydaktyczne uwarunkowania doboru lektury dla dzieci 7-10 letnich, [w:] Walory edukacyjne literatu- 
ry dziecięcej, red. J. Chruścińska, E. Kubisz, Centtrum Ustawicznego Kształcenia Bibliotekarzy, Warszawa 2000.

Hartwig-Sosnowska J., Wyobraźnia bez granic, Młodzieżowa Agencja Wydawnicza, Warszawa 1987.

Karwowska-StruczykD.,Rozwójdzieciaichaktywność,,,Wychowanie w Przedszkolu" 4(2000).

Klus-Stańska D., Kruk J., Tworzenie warunków dla rozwojowej zmiany poznawczej i konstruowania wiedzy przez dziecko, [w:] Pedagogika wczesnoszkolna-dyskursy, problemy, rozwiazania, red. D. Klus-Stańska, M. Szczepska-Pustkowska, Wydawnictwa Akademickie i Profesjonalne, Warszawa 2009.

Klus-Stańska D., Od niechęci wobec dziecięcej samodzielności myślenia do przekazu fikcji społecznej, „Studia Pedagogiczne Uniwersytetu Humanistyczno-Przyrodniczego Jana Kochanowskiego" 18(2009).

Klus-Stańska D., Światy dziecięcych znaczeń, Wydawnictwo Akademickie „Żak”, Warszawa 2004.

Kostecka W., Tajemnica księgi. Tropami wspótczesnej fantastyki dla dzieci i młodzieży, Wydawnictwo Naukowe Scholar, Warszawa 2010.

Krasuska-Betiuk M., Badania kultury literackiej młodzieży studiujacej. Propozycja teoretyczno- metodologiczna, „Kultura i Edukacja” 3(2004).

Leszczyński G., O krytyce książki dziecięcej, [w:] tenże, Literatura i książka dziecięca, Centrum Edukacji Bibliotekarskiej, Informacyjnej i Dokumentacyjnej, Warszawa 2003.

Melosik Z., Szkudlarek T., Kultura, tożsamość i edukacja. Migotanie znaczeń, Oficyna Wydawnicza „Impuls”, Kraków 1998.

Papuzińska J., Drukowanq ścieżka, Wydawnictwo Literatura, Łódź 2000.

Papuzińska J., Inicjacje literackie, Wydawnictwa Szkolne i Pedagogiczne, Warszawa 1981.

Podstawa programowa z komentarzami, t. 2: Język polski w szkole podstawowej, gimnazjum i liceum, MEN, Warszawa 2009.

Stownik literatury dziecięcej i młodzieżowej, red. B. Tylicka, G. Leszczyński, Zakład Narodowy im. Ossolińskich, Wrocław 2002. 
Stępkowski D., (R)ewolucja prakseologiczna w myśleniu i działaniu pedagogicznym wedlug Dietricha Bennera, „Seminare” 24(2007).

Szefler E., Ksiażka literacka dla dziecka w edukacji wczesnoszkolnej, WSP w Bydgoszczy, Bydgoszcz 1998.

Wajda A., Metodyka i organizacja czytelnictwa. Zarys ogólny, WSP w Bydgoszczy, Bydgoszcz 1979.

Wygotski L., Myślenie i mowa, tłum. z jęz. ros. E. Flesznerowa, J. Fleszner, Państwowe Wydawnictwo Naukowe, Warszawa 1989.

Wygotski L., Narzędzie i znak w rozwoju dziecka, thum. jęz. ros. B. Grell, Państwowe Wydawnictwo Naukowe, Warszawa 1978.

Zlota Lista Ksiażek do czytania dzieciom opracowana przez Fundacje ABCXXI - Cata Polska czyta dzieciom, dostępna na: http://www.calapolskaczytadzieciom.pl/zlota-lista, (dostęp: 11.05.2011).

\section{CALL FOR SELF-ACTIVITY IN THE CONTEXT OF THE SELECTION OF BOOKS FOR CHILDREN BY TEACHERS}

A book is an important mean of cultural message, a source of knowledge which shapes needs and aesthetic assessments. Child's contact with a book requires a strong adult intermediator, because the manifestation of reading requirements is not obvious for children's development; this is the consequence of the initiation process, where a book is brought within personal experiences of a child and a literary contact. The main objects of the article is: to describe mediating adults in the contact between a child and a book as the effect of the decisions and choices of adult intermediaries, to present criteria for selecting books of children's literature published in scientific publications and to report the research results about reading preferences of intermediaries.

The conception of the article is based on theory formulated by Dietrich Benner about call for self-activity as a pedagogical activity. In this context article discusses the possible impact of pedagogical activity through the selection of books for children and shows the child's 
contact with the book as an area of teaching the awareness of the different cultural proposals and skill of individual selection from existing options.

\section{Key words}

Children's literature, intermediator, call for self-activity, criteria for selecting books, reading preferences. 